\title{
Supplementation of Calcium-Fatty Acid to Increase Milk Production and Performance of Lactating Dairy Cow
}

\author{
Wina E, Widiawaty Y, Tangendjaja B, Susana IWR \\ Balai Penelitian Ternak, PO Box 221 Bogor 16002 \\ E-mail: ewina2013@gmail.com \\ (Diterima 30 Oktober 2014 : disetujui 19 Desember 2014)
}

\begin{abstract}
ABSTRAK
Wina E, Widiawaty Y, Tangendjaja B, Susana IWR. 2014. Suplementasi kalsium-asam lemak pada sapi perah laktasi untuk meningkatkan produksi susu dan performans induk. JITV 19(4): 287-293. DOI: http://dx.doi.org/10.14334/jitv.v19i4.1096

Salah satu sumber energi untuk pakan sapi perah adalah lemak atau minyak, tetapi pemakaian lemak atau asam lemak yang tinggi ( $>5 \%$ dalam total ransum) akan menyebabkan efek negatif terhadap fermentasi rumen. Oleh sebab itu, lemak atau asam lemak harus diproteksi sehingga tidak dapat dipecah di dalam rumen. Tujuan penelitian ini adalah untuk mengevaluasi asam lemak yang berasal dari hasil samping minyak sawit yang diproteksi (dibuat di institusi sendiri) dan ditambahkan ke dalam pakan sapi perah. Percobaan pertama adalah kegiatan evaluasi secara in vitro. Dua jenis pakan yaitu pakan komplit tidak ditambah atau ditambah dengan Kalsium asam lemak (Ca-FA) diuji secara in vitro dengan parameter yang diukur adalah $\mathrm{pH}$, total gas, amonia dan kecernaan BK pakan. Percobaan kedua adalah percobaan pemberian pakan dengan dua perlakuan diberikan pada sapi perah. Digunakan 12 ekor sapi perah FH laktasi dibagi dalam 2 grup; grup pertama diberi pakan yang mengandung 300g Ca-FA (2.5\% dari total ransum) dan grup kedua adalah perlakuan kontrol tanpa suplementasi Ca-FA. Pakan diberikan sebagai total mixed ration terdiri rumput gajah, jagung giling, bungkil kedelai, polar dan bungkil kepala dengan kandungan protein $15,1 \%$ dan net energi untuk laktasi 1,53 Mcal/kg. Pemberian pakan diberikan pada sapi satu bulan sebelum melahirkan hingga mencapai 120 hari masa laktasi. Produksi susu dicatat setiap hari. Pada akhir percobaan dilakukan pengumpulan feses selama 1 minggu untuk mengukur total kecernaan pakan. Hasil dari percobaan in vitro menunjukkan tidak adanya efek negatif dari penambahan Ca-FA terhadap parameter fermentasi rumen dan meningkatkan nilai kecernaan pakan (KCBK Ca-FA dibanding kontrol $=58,52 \%$ dibanding 53,99\%). Percobaan pemberian pakan memperlihatkan bahwa penambahan Ca-FA meningkatkan produksi susu (11,41 dibanding 10,74 liter/hari pada kontrol) tetapi tidak mempengaruhi konsumsi, nilai total kecernaan dan kualitas susu. Bobot badan sapi yang diberi Ca-FA lebih tinggi dari pada sapi kontrol yang tidak diberi Ca-FA. Hasil penelitian ini menunjukkan manfaat positif dari penggunaan Kalsium-asam lemak (Ca-FA) dalam pakan sapi perah. Kesimpulan bahwa suplementasi Ca-FA sebanyak 300g/ekor/hari pada sapi perah laktasi dapat meningkatkan produksi susu tanpa menyebabkan efek negatif.
\end{abstract}

Kata Kunci: Kalsium-Asam Lemak, Sapi Perah, Susu, Produksi, Kualitas

\section{ABSTRACT}

Wina E, Widiawaty Y, Tangendjaja B, Susana IWR. 2014. Supplementation of calcium-fatty acid to lactating cow to increase milk production and performance of dairy cow. JITV 19(4): 287-293. DOI: http://dx.doi.org/10.14334/jitv.v19i4.1096

One of energy sources for feeding dairy cow is fat or oil, however, inclusion of fat or fatty acid at high level (>5\% in the diet) may cause negative effect on rumen fermentation. Fat or fatty acid, therefore should be protected from its degradation in the rumen. The aim of this experiment was to evaluate protected product of palm oil fatty acid (Calcium fatty acid) made in the institute as feed supplement given on top of the ration. The first experiment was in vitro experiment using rumen liquor. Feed without and with Calcium fatty acid (Ca-FA) was incubated in buffer-rumen liquor and $\mathrm{pH}$, total gas, ammonia and in vitro digetibility were measured. The second experiment was feeding trial with two treatments using 12 FH dairy cow divided into 2 groups with diet containing supplementation $300 \mathrm{~g}$ of Ca-FA and other group is control treatment without supplementation. The feed was total mixed ration, comprises of elephant grass, ground corn, soybean meal, wheat pollard and coconut meal with protein content $15.1 \%$ and Net Energy for Lactation $1.53 \mathrm{Mcal} / \mathrm{kg}$.. Feed was given to cow one month before parturition until 120 days of lactation period. Milk production was recorded daily. Faeces collection was done at the end of the experiments for 1 week to calculate total tract digestibility. The result of the in vitro experiment showed that no negative effect on in vitro rumen fermentation except higher digestibility (DMD Ca-FA addition vs control were 58.52\% vs 53.99\%) occurred due to addition of Ca-FA. The addition of Ca-FA increased milk production (11.41 vs 10.74 litre/day), but no effect on intake, total tract digestibility and milk quality, higher body weight of cow than control cow showing the benefit of using Ca-FA in the diet of dairy cow. In conclusion supplementation of Ca-FA at $300 \mathrm{~g}$ would be beneficial to increase milk production without negative impact.

Key Words: Calcium-Fatty Acid, Dairy Cow, Milk, Production, Quality 


\section{INTRODUCTION}

Feed is a very important factor that influences milk production and performance of dairy cow. During early lactation, dairy cows need more energy to produce milk and for maintenance. However, cow's ability to consume dietary energy is lower than the requirement of energy for producing milk, resulting in a negative energy balance (Harvatine \& Allen 2005). Energy source can be obtained from grains or cereals by products. Fat or fatty acids is also an energy source which is high density. It produces higher energy than carbohydrate or protein. NRC (2001) stated that the energy value of fatty acid is two times higher than carbohydrate. Inclusion high level of fat in the diet, however, can be detrimental to rumen microbes, hence disturb the rumen function. Therefore, fat or fatty acid should be protected to prevent its negative effect on rumen microbes.

Fat or fatty acids that are abundantly available in Indonesia comes from palm oil industry. At present, the production of crude palm oil in Indonesia is 26.7 million tons and 16.67 million tons are processed to cooking oil. During this process, free fatty acids and stearine as by products are obtained. These free fatty acids can be utilized as soap, cosmetics and feed ingredient. Fatty acid that given to livestock was suggested in the form of calcium fatty acid or chill prilled fat. Production of calcium fatty acid palm oil in Indonesia and its usage by farmers are still very limited.

Feeding Ca-fatty acid to dairy cows varied between 2.5-4\% of total diet. Ca-fatty acid that contained high unsaturated fatty acid decreased the feed consumption of lactating cows while the hydrogenated fatty acid (prilled fat) containing saturated fatty acid did not reduce intake (Karcagi et al. 2010).

Feeding $3 \%$ calcium fatty acid to dairy cows increased milk production from $18.88 \mathrm{~kg} / \mathrm{day}$ to $22.48 \mathrm{~kg} /$ day (Maeng et al. 1993). Similarly, Reis et al. (2012) reported that improved milk production was achieved by giving calcium-fatty acid (poly unsaturated fatty acids) to dairy cow. It was concluded from metaanalysis study that supplementing dairy cows with $\mathrm{Ca}$ fatty acid or prilled fat increased milk production (Rabiee et al. 2012).

Ca-FA (Calcium fatty acid) produced at Indonesian Research Institute for Animal Production has previously been tested to sheep and gave a significant increase of weight gain (Lubis et al. 1998). Ca-fatty acid that given to ewe also reduced the loss of ewe's body weight after parturition (Wina et al. 1996).

This experiment aimed to improve milk production and quality of dairy cow fed with Ca-FA as a supplement and to reduce the body weight loss of dairy after parturition.

\section{MATERIALS AND METHODS}

The experiment was conducted at the experimental station of the Indonesian Research Institute for Animal Production using 12 lactating cows. The fatty acid was bought as by products of cooking oil industry and made into Calcium fatty acid (Ca-FA) at the experimental laboratory of Indonesian Research Institute for Animal Production. Other feed ingredients were bought from local trader. Fatty acid of palm oil was heated and became liquid. It was, then, reacted with sodium hydroxide and calcium chloride to become granules of calcium fatty acid (Ca-FA).

\section{In vitro rumen fermentation}

There were two types of sample. The first sample was the control feed without addition of Ca-FA as described in Table 1 . The second sample was the diet contained $2.5 \%$ of Calcium fatty acid. One gram of feed sample with or without Ca-FA was weighed and placed into a bottle containing $75 \mathrm{ml}$ of ruminal liquid and buffer solution and incubated at $39^{\circ} \mathrm{C}$ for 48 hours. There were three replicates for each sample. Rumen fluid was collected just before morning feeding from a rumen fistulated Friesian Holstein cow fed with commercial concentrate and elephant grass. The ruminal liquid and buffer medium was consisted bicarbonate buffer solution: (24.1\%), macro-mineral solution: $(12.1 \%)$, micro-mineral solution: $(0.00613 \%)$, resazurin: $(0.0612 \%)$, distilled water: $(36.2 \%)$, reducing solution: (2.3\%) and rumen fluid: (25.3\%) (Makkar 2003). Total gas and methane were measured at 3, 6, 9, $12,24,30,36,48$ hours of fermentation. The supernatant was separated by filtration to obtain residue and supernatant. The residue was dried in the oven and weighed. Ash content of feed and residue was determined according to AOAC method (2000) and NDF and ADF analysis was conducted following Goering and Van Soest method without addition of amylase (1970). The in vitro dry matter (DM) and organic matter (OM) of digested fractions were calculated from the dry matter and organic matter of initial sample minus those of residue. The DM or OM of digested fractions divided by the DM or OM of initial sample was calculated as in vitro dry matter or organic matter digestibilities. Ammonia content in the supernatant was determined using Conway microdiffusion technique. Protozoa was stained with methyl green formalin saline solution and counted under microscope.

\section{Feeding trial of Ca-FA to lactating cow}

Twelve lactating cows of Friesian Holstein at early lactation or one month before parturition were housed 
individually in concrete floor-tie stalls with concrete feeding troughs. The cows were divided into 2 treatments with and without Ca-FA (Ca-fatty acid). They were fed with total mixed ration with its composition is presented in Table 1. The whole diet contained $1.53 \mathrm{Mcal} / \mathrm{kg}$ Net Energy Lactation and $152 \mathrm{~g}$ of $\mathrm{CP} / \mathrm{kg}$ of total feed. Fresh grasses were harvested in the morning, chopped to $10-20 \mathrm{~cm}$ length, thoroughly hand mixed and fed ad libitum (10\% refusal rate) at $10: 00 \mathrm{~h}$ and $15: 00 \mathrm{~h}$ on the same day. Water was available ad libitum. A total mixed ration was applied and the feed composition is presented in Table 1. CaFA was given on top of the feed $(300 \mathrm{~g} / \mathrm{head} / \mathrm{day}$ or $2.5 \%$ of total diet). The feed was given to the cows one month before parturition until reached 120 days of lactation period. The feed and residue was weighed every day. The cows were milked twice a day and milk production was recorded daily. Milk quality was measured once a month using Milk Scan After the milk production was collected and measured in the morning, subsample of milk was taken for measuring milk quality. Faeces collection was done at the end of the experiments for 1 week to calculate total tract digestibility. Daily, subsamples of faeces, residue and offered feed were taken and dried in the oven at $60^{\circ} \mathrm{C}$ for 2 days. These subsamples of each animal were combined and ground using wiley mill to be further analysed at the Analytical Laboratory of Indonesian Research Institute for Animal Production, Bogor for their ash and protein content (AOAC 2000) and NDF and ADF content (Goering \& Van Soest 1970).

Table 1. Composition of dairy feed during experiment

\begin{tabular}{ll}
\hline \hline Feed ingredient & $\% \mathrm{DM}$ \\
\hline King grass (fresh) & 36.8 \\
Wheat pollard & 18.9 \\
Ground corn & 19.4 \\
Soybean meal & 8.0 \\
Coconut meal & 14.0 \\
Molases & 0.9 \\
Ground limestone & 1.5 \\
Salt & 0.25 \\
Premix & 0.25 \\
Calculated Nutrient composition & \\
Total digestible nutrient (\%) & 67.11 \\
Crude protein (\%) & 15.19 \\
Net Energy Lactation (Mcal/kg) & 1.53 \\
Ca (\%) & 0.88 \\
P (\%) & 0.56 \\
\hline
\end{tabular}

\section{Statistical analysis}

Both data of in vitro experiment and in vivo experiment were statistical analysed by PROC GLM using SAS package version 9. Further analysis used Duncan's test for significant difference.

\section{RESULTS AND DISCUSSION}

The result of incubating feed with and without $\mathrm{Ca}$ FA (Ca-fatty acids) in the in vitro fermentation batch system is presented in Table 2 . pH solution after the feed was fermented for 48 hours was not different between treatments. Ca-FA is a calcium salt of palm oil fatty acid which $\mathrm{pH}$ is neutral $(=7)$, therefore addition of $\mathrm{Ca}-\mathrm{FA}$ to dairy feed did not affect rumen $\mathrm{pH}$. Inclusion of Ca-FA did not significantly reduce total gas and methane production although the value of total gas and methane production was lower than the control treatment (Table 2). Total gas consisted mainly $\mathrm{CO}_{2}$ and methane was produced because of the degradation of organic matter in the diet by ruminal microbes. Protozoa population was not different between treatments showing that addition Ca-FA did not negatively affect rumen fermentation and microbial population.

In the rumen, when fatty acid was in the free form, the degree of unsaturation affected its toxicity to ruminal microbes. The higher the degree of unsaturation, the higher the toxicity (Maia et al. 2010). The major fatty acids of palm oil were palmitic acid (C16:0, 53.9\% of total fatty acid) and oleic acid (C18:1, $33 \%$ of total fatty acid). However, the unsaturated fatty acids of palm oil fatty acid in Ca-FA were protected, hence, did not cause any toxicity to the rumen microbes.

Suprisingly addition of Ca-FA to the diet increased significantly $(\mathrm{P}<0.05)$ in vitro dry matter and organic matter digestibilities. Tangendjaja et al. (1993) reported that the in vitro DM digestibility reduced as Ca-FA was included $10-50 \%$ in the diet. The reduction of DM digestibility did not happen in this experiment since the inclusion level of Ca-FA was only $2.5 \%$ and this level may be too low to give any negative effect.

Table 3 shows the daily consumption of dry matter, organic matter, protein, NDF and ADF and energy. None of the daily consumption was significantly different between treatments $(\mathrm{P}>0.05)$ although addition of Ca-FA slightly increase dry matter, organic matter and gross energy intakes. It was reported that after parturition, dairy cow usually had lower intake and causing less energy availability for producing milk. Therefore, protected fat was often added to the diet to increase higher energy intake. Contribution of Ca-FA to 
Table 2. The effect of Calcium fatty acid addition on in vitro fermentation products, digestibilities and protozoa population

\begin{tabular}{lcccc}
\hline \hline & & Feed without Ca-FA & Feed with Ca-FA addition & sem \\
\hline $\mathrm{pH}$ & & 6.72 & 6.51 & 8.88 \\
Total gas & $\mathrm{ml}$ & 161.8 & 137.5 & 2.74 \\
Methane & $\mathrm{ml}$ & 26.9 & 21.5 & 3.61 \\
Ammonia & $\mathrm{mg} / \mathrm{l}$ & 207.23 & 219.74 & 1.01 \\
DM digestibility & $\%$ & $53.99^{\mathrm{a}}$ & $58.52^{\mathrm{b}}$ & 0.93 \\
OM digestibility & $\%$ & $56.31^{\mathrm{a}}$ & $59.87^{\mathrm{b}}$ & \\
Protozoa population & $10^{5}$ & 2.5 & 4.0 & \\
\hline
\end{tabular}

Table 3. The effect of Calcium fatty acid addition on daily intake of feed

\begin{tabular}{lcc}
\hline \hline Parameter & Feed without Ca-FA & Feed with Ca-FA addition \\
\hline Dry matter (kg/day) & $13.10 \pm 1.38$ & $13.37 \pm 1.44$ \\
Organic matter (kg/day) & $12.02 \pm 1.27$ & $12.28 \pm 1.34$ \\
Protein (kg/day) & $1.77 \pm 0.21$ & $1.76 \pm 0.25$ \\
NDF (kg/day) & $6.64 \pm 0.74$ & $6.64 \pm 0.67$ \\
ADF (kg/day) & $3.56 \pm 0.43$ & $3.54 \pm 0.33$ \\
Gross Energy (Mcal/day) & $53.47 \pm 5.82$ & $57.33 \pm 6.54$ \\
\hline
\end{tabular}

the dry matter and gross energy total intake was only $2.5 \%$ but it was expected that the fatty acid from Ca-FA was not degraded in the rumen and this would be directly utilized by the animal as a form of energy. This energy would be used for milk production.

Total tract digestibility values of dry matter, organic matter, protein, NDF, ADF and energy were also not significantly different $(\mathrm{P}>0.05$; Table 4$)$. These results were in agreement with Manso et al. (2006) who reported that $\mathrm{Ca}-\mathrm{FA}$ at $4 \%$ inclusion did not cause any negative effect on DM, OM or fiber digestibility. It was reported that the effect of fat (higher than $5 \%$ in the diet) would negatively affect rumen microbes especially cellulolytic microbes because the fat (oil) layer prevent the microbes to degrade the feed. By protecting the fat, this complex would not be degraded in the rumen suggesting no interference of fat and it was stable in the rumen. However, at low $\mathrm{pH}$ condition in the abomasum, this complex would be degraded releasing the fatty acid which would be absorbed in the small intestine (Jenkins \& Palmquist 1984).

Increasing level of calcium salt of fatty acid decreased digestibility in the rumen but not in this experiment. DM, protein and fibre digestibilities were not affected when fed Calcium fat as also reported by Voigt et al. (2006). However, fat digestibility increased
Table 4. The effect of Calcium fatty acid addition on digestibility values $(\%)$ of feed

\begin{tabular}{lcc}
\hline \hline Parameter & $\begin{array}{c}\text { Feed without } \\
\text { Ca-FA }\end{array}$ & $\begin{array}{c}\text { Feed with Ca- } \\
\text { FA addition }\end{array}$ \\
\hline Dry matter (\%) & $67.21 \pm 4.40$ & $65.98 \pm 5.39$ \\
Organic matter (\%) & $68.10 \pm 4.35$ & $66.98 \pm 5.34$ \\
Protein (\%) & $77.51 \pm 3.71$ & $76.80 \pm 3.01$ \\
NDF (\%) & $55.38 \pm 5.41$ & $53.46 \pm 6.75$ \\
ADF (\%) & $44.91 \pm 6.65$ & $43.22 \pm 8.14$ \\
Gross Energy (\%) & $68.33 \pm 4.53$ & $67.69+5.36$ \\
\hline
\end{tabular}

significantly when Calcium fat was given to male cattle (Voigt et al. 2006).

The average milk production curve is presented in Figure 1. It shows that during initial milk production, there was no difference between treatments, but after 30 days of experiment, milk production of cow that received $\mathrm{Ca}-\mathrm{FA}$ started to decline at a slower rate than that received no Ca-FA. The difference between treatments is clearly seen after 66 days of experiment. From linier regression, it shows that milk production of cow fed with Ca-FA declined at the rate of 0.024 


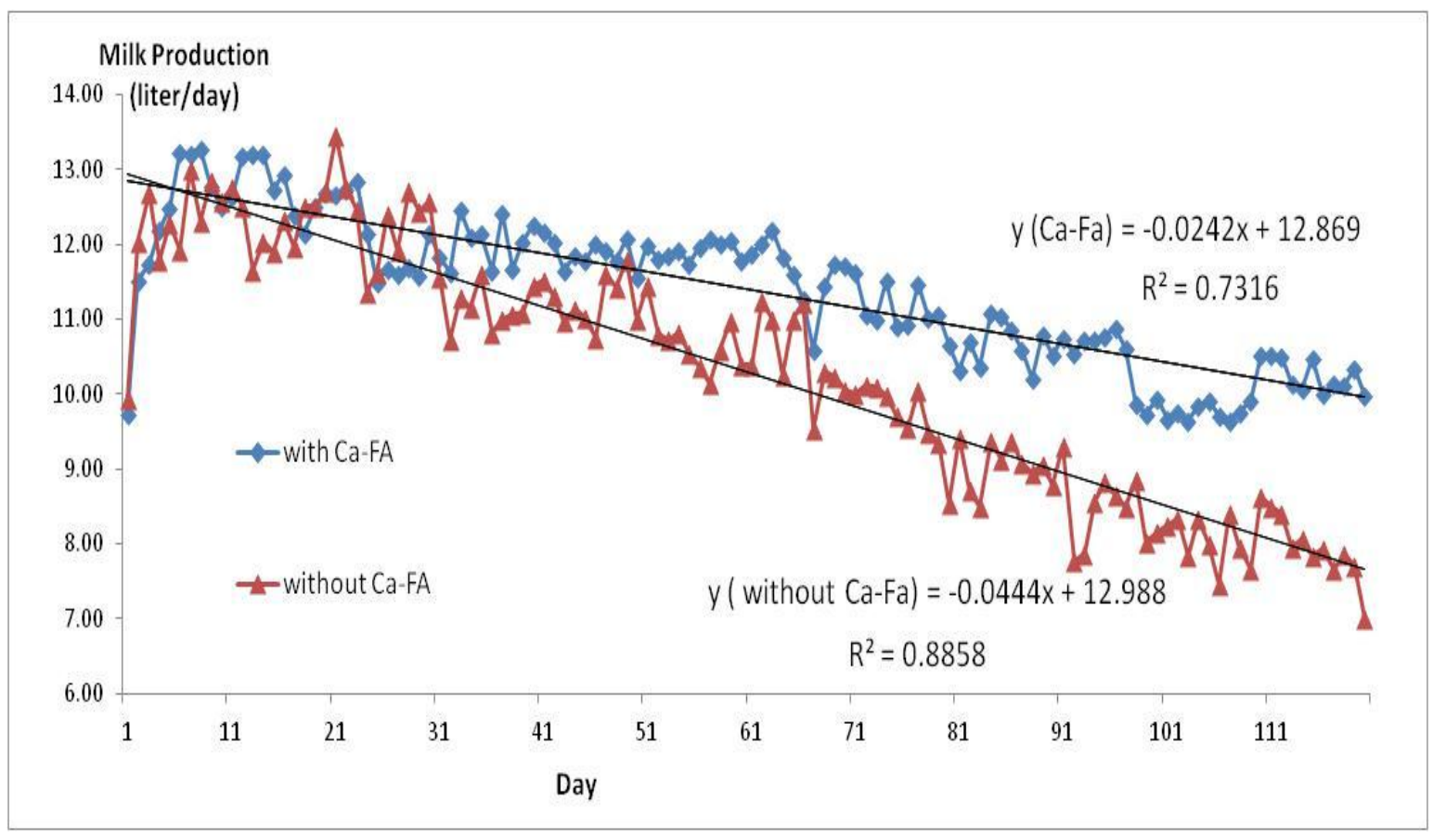

Figure 1. Average milk production curve of cows receiving diet containing Ca-FA and diet without Ca-FA during experiment

Table 5. The effect of Ca-FA addition to dairy feed on milk quality (\%)

\begin{tabular}{lccccc}
\hline \hline & Fat & SNF & Total solid & Lactose & Protein \\
\hline Feed without Ca-FA & $3.63 \pm 0.42$ & $7.04 \pm 0.97$ & $10.73 \pm 0.65$ & $3.96 \pm 0.10$ & $2.80 \pm 0.18$ \\
Feed with Ca-FA addition & $3.60 \pm 0.11$ & $7.89 \pm 0.55$ & $11.10 \pm 0.10$ & $4.16 \pm 0.40$ & $2.85 \pm 0.22$ \\
Standard error & 0.14 & 0.35 & 0.33 & 0.13 & 0.09 \\
\hline
\end{tabular}

liter/day while that of cow fed without Ca-FA declined at the rate of 0.044 liter/day. Feeding Ca-FA may provide additional energy to lactating cow so the milk production could be maintained and did not decline as fast as control treatment. Average milk production for 4 months produced by dairy cows fed Ca-FA was higher than that produced by control cow (11.41 vs 10.74 litre/day). This experiment was in agreement with Karcagi et al. (2010) who reported that feeding Ca-fatty acid of palm oil increased milk production and Shibata et al. (2011) also reported an increase of $7.41 \%$ on milk production when cow were supplemented with $400 \mathrm{~g}$ of protected rapeseed oil. Maeng et al. (1993) reported that feeding $3 \%$ calcium fatty acid to dairy cows increased milk production from $18.88 \mathrm{~kg} /$ day to $22.48 \mathrm{~kg} /$ day (increase 19\%). This experiment confirmed the previous experiments reported by other authors that protected fatty acid including $\mathrm{Ca}-\mathrm{FA}$, produced locally by the Indonesian Research Institute for Animal Production improved milk production. Wina \& Susana (2013) has described the metabolism of fat in the digestive tract of ruminant. After passing the rumen, fatty acid from protected fatty acid will be used mainly for milk fat synthesis when cow is on the negative energy balance (lack of energy) during early lactation and it will be used for body fat deposition and milk fat synthesis when cow is in the positive energy balance (Van Knegsel et al. 2007).

Addition of Ca-FA to cow's feed did not give any significant effect on milk quality including SNF, total solid, lactose content (Table 5). Standard deviation of each parameter was quite high so that there was no significant difference. Other reports showed no consistent effect of Ca-fatty acid on milk quality. Rabiee et al. (2012) using meta-analysis reported that fat content in milk increased with Ca-fatty acid and prill fat of palm oil but it can be reduced with other source of Ca-fatty acids. Other researcher, Karcagi et al. (2010) found a significant reduction on milk fat content but not milk fat yield by feeding Ca-fatty acid which may inhibit fat synthesis in milk (Hammon et al. 2007). The different results on the effect of Ca-fatty acid on fat 
content of milk suggested that the effect was influenced by different source and level of inclusion of Ca-fatty acid in the feed. Protein content in milk in this experiment was not significantly reduced with supplementation of Ca-fatty acid and this was also in agreement with the study according to Rabiee et al. (2012).

Body weight of dairy cow decreased significantly after calving but it started to increase after one month of milk production. Up to 3 months of experiments, The average increase of body weight of cows fed with $\mathrm{Ca}$ FA was higher than that of control animal without CaFA (147 g/day vs 77.6 g/day, respectively). This result shows that Ca-FA contributes as energy source to dairy cow as calcium fat gave higher energy almost twice than energy from cereals (Voigt et al. 2006). It is assumed that Ca-FA will give a positive effect on preparing dairy cow for the next pregnancy. Trends in increased pregnancy rates of cow fed protected fat mixed with corn gluten feed was observed by Long et al (2007). Although in this experiment, reproduction performance was not observed, protected fat in the dairy diet was reported not only just adding calories (energy) for milk production but also improved reproduction (Reis et al. 2012)

\section{CONCLUSION}

Feeding Ca-FA at the level of $2.5 \%$ of total diet of lactating animals improved milk production by $7.41 \%$ with no effect of Ca-FA on milk quality and nutrient digestibility of feed. Ca-FA contributes additional energy that increased body weight of cow higher than control after calving

\section{REFERENCES}

[AOAC] Association of Official Analytical Chemists. 2000. Official methods of analysis. 17th ed. Arlington (USA): Association of Official Analytical Chemists.

Goering HK, Van Soest PJ. 1970. Forage Fiber Analysis (apparatus, reagents, prosedures and some applications). USDA Agricultural Handbook. 379.

Hammon HM, Metges CC, Junghans P, Becker F, Bellmann O, Scheider F, Nurnberg G, Dubreuil P, Lapierre H. 2007. Metabolic changes and net portal flux in dairy cows fed a ration containing rumen protected fat as compared to a control diet. J Dairy Sci. 91:208-217. doi: 10.3168/jds.2007-0517.

Harvatine KJ, Allen MS. 2005. The effect of production level on feed intake, milk yield and endocrine responses to two fatty acid supplements in lactating cows. J Dairy Sci. 88:4018-4027.
Jenkins TC, Palmquist DL. 1984. Effect of fatty acids or calcium soaps on rumen and total nutrient digestibility of dairy rations. J Dairy Sci. 67:978-986.

Karcagi RG, Gaal T, Ribiczey P, Huszenicza G and Ferenc Husveth F. 2010. Milk production, peripartal liver triglyceride concentration and plasma metabolites of dairy cows fed diets supplemented with calcium soaps or hydrogenated triglycerides of palm oil. J Dairy Res. 77:151-158. doi:10.1017/S0022029909990604.

Long NM, Hill GM, Baker JF, Graves WM, Froetschel MA, Keisler DH, Mullinix BG, Jr 2007. Reproductive performance of beef heifers supplemented with corn gluten feed and rumen-protected fat before breeding. Prof Anim Sci. 23:316-324.

Lubis D, Wina E, Rubiono BE.1998. Growth rate of sheep fed high fat ration. JITV. 3:143-148.

Maeng WJ, Lim JH, Lee SR. 1993. Effects of calcium salts of long-chain fatty acids on ruminal digestibility, microbial protein yield and lactation performance. AJAS. 6:395400.

Maia MRG, Chaudhary LC, Bestwick CS, Richardson AJ, McKain N, Larson TR, Graham IA, Wallace RJ. 2010. Toxicity of unsaturated fatty acids to the biohydrogenating ruminal bacterium, Butyrivibrio fibrisolvens 10:52. http://www.biomedcentral.com/ $1471-2180 / 10 / 52$.

Makkar HPS. 2003. Quantification of tannin in tree and shrub foliage. A laboratory manual. Netherlands: Kluwer Academic Publishers.

Manso T, Castro T, Mantec'on AR, Jimeno V. 2006. Effects of palm oil and calcium soaps of palm oil fatty acids in fattening diets on digestibility, performance and chemical body composition of lambs. Anim Feed Sci Technol. 127:175-186.

[NRC] National Research Council. 2001 Nutrient requirements of dairy cattle. 7 th revised ed. Washington DC (USA): National Academy Press.

Rabiee AR, Breinhild K, Scott W, Golder HM, Block E, Lean IJ. 2012. Effect of fat additions to diets of dairy cattle on milk production and components: A meta-analysis and meta-regression. J Dairy Sci. 95:3225-3247. http://dx.doi.org/ 10.3168/jds.2011-4895.

Reis MM, Cooke RF, Ranches J, Vasconcelos JL. 2012. Effects of calcium salts of poly unsaturated fatty acids on productive and reproductive parameters of lactating Holstein cows. J Dairy Sci. 95:7039-7050. doi: 10.3168/jds.2012-5502.

Shibata H, Hashizume N, Gazi MR, Sera K, Kato E, Ohmor T, Kanbe M, Obara Y, Kanda S, Kukawa Y, Itabashi H. 2011. Effect of supplementation of soy sauce oil and $\mathrm{Ca}$ salts of fatty acids on rumen fermentation, milk production and conjugated linoleic acid in milk of dairy cows. Anim Sci J. 82:554-559. doi: 10.1111/j.17400929.2011.00875.x. 
Tangendjaja B, Santoso B, Wina E 1993. Protected fat: Technology and digestibility. Advances in Small Ruminant Research in Indonesia. ARRD-SRCP, Bogor. p. $105-114$.

Van Knegsel AT, Van Den Brand H, Dijkstra J, Van Straalen WM, Heetkamp MJ, Tamminga S, Kemp B. 2007. Dietary energy source in dairy cows in early lactation: energy partitioning and milk composition. J Dairy Sci. 90:1467-1476.

Voigt J, Kuhla S, Gaafar K, Derno M, Hagemeister H. 2006. Digestibility of rumen protected fat in cattle. Slovak J Anim Sci. 39:16-19.
Wina E, Tangendjaja B. 1996. Protected fat supplementation for pregnant and lactating ewes. In: Merkel R, Soedjana TD, Subandriyo, editors. Small ruminant production: Recommendations for Southeast Asia. Small ruminant collaborative research support program with Indonesia Agency for Agriculture Research and Development. Indonesia. p. 217-224

Wina E, Susana IWR. 2013. Manfaat lemak terproteksi untuk meningkatkan produksi dan reproduksi ternak ruminansia. Wartazoa. 23:176-184. 